\title{
TTR
}

Traduction, terminologie, rédaction

\section{Translating Indigeneity at the University of Alberta}

\section{Anne Malena et Julie Tarif}

Volume 31, numéro 2, 2e semestre 2018

Minorité, migration et rencontres interculturelles : du binarisme à la complexité

Minority and Migrant Intercultural Encounters: From Binarisms to Complexity

URI : https://id.erudit.org/iderudit/1065568ar

DOI : https://doi.org/10.7202/1065568ar

Aller au sommaire du numéro

Éditeur(s)

Association canadienne de traductologie

ISSN

0835-8443 (imprimé)

1708-2188 (numérique)

Découvrir la revue

Citer cet article

Malena, A. \& Tarif, J. (2018). Translating Indigeneity at the University of Alberta. TTR, 31(2), 43-64. https://doi.org/10.7202/1065568ar

\section{Résumé de l'article}

Des efforts sont faits depuis quelques années pour améliorer les relations asymétriques qui existent au Canada entre les Premières Nations, les Métis, les Inuit et le peuple non autochtone. Les institutions post-secondaires jouent un rôle clé dans cette entreprise d' "Indigénisation », et plusieurs d'entre elles s'attachent, par le biais de projets novateurs, à rendre l'environnement universitaire plus inclusif pour les étudiants autochtones. Cette étude s'intéresse aux stratégies utilisées par l'Université de l'Alberta (Edmonton) pour faire face à ce défi et postule qu'il est important de mettre en place une forme de traduction activiste au sein de cette entreprise afin de redresser les torts du colonialisme. 


\title{
Translating Indigeneity at the University of Alberta ${ }^{1}$
}

\author{
Anne Malena \\ University of Alberta \\ Julie Tarif \\ University of Alberta
}

\begin{abstract}
Over the last few years there has been an attempt to redress the asymmetrical relations between Canada's First Nations, Métis, and Inuit people, and the non-Indigenous people in Canada. Post-secondary education plays a prominent role in this endeavour and many institutions across Canada are currently working on innovative ways to make their environment more inclusive, or what is called "Indigenizing" the academy. This study focuses on how the University of Alberta (Edmonton) is meeting this challenge and argues that a form of activist translation needs to be an important part of this endeavour in order to redress damages caused by colonialism.
\end{abstract}

Keywords: indigenizing, universities, TRC, translation, space

\section{Résumé}

Des efforts sont faits depuis quelques années pour améliorer les relations asymétriques qui existent au Canada entre les Premières Nations, les Métis, les Inuit et le peuple non autochtone. Les institutions post-secondaires jouent un rôle clé dans cette entreprise d' «Indigénisation», et plusieurs d'entre elles s'attachent, par le biais de projets novateurs, à rendre l'environnement universitaire plus inclusif pour les étudiants autochtones. Cette étude s'intéresse aux stratégies utilisées par l'Université de l'Alberta (Edmonton) pour faire face à ce défi et postule qu'il est important de mettre en place une forme de

1. Previous versions of this article were presented, first at the annual St. Jerome's Day Conference on September 30,2017 at the University of Alberta, and second at the "Lost and Found in Transcultural and Interlinguistic Translation" Conference at the University of Moncton on November 3. We wish to gratefully acknowledge the insightful review of this article and to express our deepest gratitude for the excellent reviewers' suggestions we received. 
traduction activiste au sein de cette entreprise afin de redresser les torts du colonialisme.

Mots-clés : indigénisation, universités, CVR, traduction, espace

If you come and break the windows to my house, you're going to have to fix those windows before

I'll entertain your apology.

(a Kanien'kehá:ka ka audience member at the 2013 Quebec

National Event hosted by the Truth and Reconciliation

Commission of Canada on Indian residential schools; quoted in Robinson and Martin, 2016, p. 1)

\section{Introduction}

Over the last few years there has been an attempt to redress the asymmetrical relations between Canada's First Nations, Métis, and Inuit people, and the non-Indigenous people in Canada. Postsecondary education plays a prominent role in this endeavour and many institutions across Canada are currently working on innovative ways to make their environment more inclusive as a result of the Truth and Reconciliation Commission's (TRC) Report and its 94 Calls to Action (Truth and Reconciliation Commission of Canada, 2015). The University of Alberta, our focus for this project, launched its campaign for "Indigenizing" in 2016 and we have been exploring this sort of "reverse autoethnographical" move, undertaken by settlers, or "colonizing" subjects, to represent themselves in ways that engage with the "colonized" subjects' own terms ${ }^{3}$. The translation perspective we chose first led us to analyze the discourse of several official documents, such as the TRC final report (Truth and Reconciliation Commission of Canada, 2015), Truth and Reconciliation Commission of Canada: Calls to Action (Truth and Reconciliation Commission of Canada, 2012), and the United Nations Declaration on the Rights of Indigenous Peoples (United Nations, 2008), in order to determine whether the transcultural dialogue hoped for by academic institutions is possible between Indigenous and non-Indigenous people, and whether the official

2. This term is used in the Canadian academic context to describe "what universities are doing to weave indigenous peoples, cultures and knowledge into the fabric of their campuses," as Moira MacDonald puts it (2016, n.p.).

3. We are using Mary Louise Pratt's definition of autoethnography, which she identifies as "instances in which colonized subjects undertake to represent themselves in ways that engage with the colonizer's own terms" (1991, p. 35). 
texts sufficiently address issues of language, culture and, most importantly, translation. As translation scholars ${ }^{4}$ who also teach the practice and theory of translation in a Modern Languages and Cultural Studies department, we were eager to explore what "Indigenizing the University" might mean for the day-to-day activities in our classrooms. We also recognized our own limitations in this endeavour and wished to proceed carefully, in consultation with Indigenous scholars and specialists as we felt we have much to learn. It quickly became obvious that the process of "Indigenizing" is first and foremost a process of decolonization, which is necessarily slow since it involves first looking critically at our own training and understanding its Eurocentric bias before any learning of an Indigenous worldview can be undertaken. This article, therefore, aims at presenting the prolegomena of our initial investigation, based broadly on the kinds of issues that have been raised at our university and focusing more closely on the intersection of space and language - in this case Cree or, more aptly, Nehiyaw - and the ensuing issue of translation.

As "Indigenizing the University" led to an impressive series of public events, starting in the fall of 2016 and still ongoing in the winter of 2019, our original idea was to conduct a series of open interviews on and off campus to find out how the call for Indigenization was received by various units and individuals already involved in the process. We drafted a common set of questions for all participants and asked additional questions pertaining to the expertise of each person. Our first participant was Papaschase ${ }^{5}$ Chief Calvin Bruneau who was one of the speakers at a public forum organized by the interdisciplinary group of scholars in charge of the Indigenizing effort. Through snowballing we ended up with a total of eight participants among whom six were Indigenous from Nehiyaw, Blackfoot, Metis, Papaschase, and Takelma Nations; the other two included a member of the interdisciplinary committee and a professor of literature in English, cross-appointed with Native Studies. All were asked 1) whether they felt that language issues were

4. It must also be made clear that we identify as first-generation immigrants, therefore settlers and would-be allies, given our interest in raising awareness of "Indigenous history amounting to Canadian history" (Dempsey, 2017, n.p.).

5. The Papaschase continue to struggle for recognition by the federal government since they were scattered through the illegal surrender of their reserve in 1886 by means of scrip and forced to transfer to other bands. See Papaschase First Nation (n.d.). 
sufficiently represented in the TRC recommendations; 2) whether it was possible to recover lost values, such as culture and dignity; 3) whether sufficient attention was being paid to Indigenous languages on campus; 4) whether they had noticed any problematic examples of translation-this question was followed by a discussion of the University's chosen territorial acknowledgment; 5) whether they had any suggestions to make as to how best to include language issues in the curricula. While we gathered data from these interviews- the results of which are disseminated throughout the article as pertinent topics are introduced-we familiarized ourselves with existing scholarship and attended as many events as possible. We learned a great deal about the history of Treaty 6 territory upon which the university is located, the long and eventually successful struggle of pluridisciplinary Native Studies to gain recognition as a Faculty, the obstacles confronting Indigenous students seeking degrees in other faculties, and current efforts - and resistance to them-in opening up spaces within programs and disciplines to include more Indigenous students and to raise awareness of Indigenous knowledges. We also realized, however, that relatively little thought was given to translation although several of the participants testified to the fact that European and Indigenous languages express very different realities. For example, what a speaker might say at the opening of an event in his or her language simply does not translate into English because it loses all of its spiritual significance in the transfer. As a result, we saw the necessity to draw from existing scholarship in postcolonial translation studies and Indigenous translation in order to gain a deeper understanding of the issues emerging out of the efforts to bring two very different worldviews closer to each other.

\section{Western Epistemology and Translation}

In his introduction to a collection of essays on Native American translation, Brian Swann notes that the "contact or collision" of different worlds "necessitates dealing with translation as part of the historical process of appropriation, and with the fact that the process of collecting and translating Native American materials is replete with ironies and dilemmas" (2011, p. 1). Marie Battiste and James Youngblood Henderson are among those who have researched such ironies and dilemmas and their work on decolonizing education at all levels has been very influential. From our perspective, the notion of the "Eurocentric illusion of benign translatability" (Battiste and Henderson, 2000, p. 79) that they discuss is at the core of the role 
played by translation in colonialism and, through the theorization of its deep-seated reasons, can inspire its reversal into awareness of the challenges posed by any translation from Indigenous languages. As Battiste and Henderson explain:

The intercultural conflict between worldviews extends beyond questions of linguistic relativity and cultural pluralism, however, to the question of translatability. The traditional Eurocentric response is that world views can be translated. (ibid., p. 41)

For them, this belief in translatability is far from innocent, as the history of destruction of Indigenous knowledge and cultural artefacts by Europeans shows. However, they identify a more subtle process at work toward assimilation through language, starting in 1492 when Indigenous languages were learned for colonial purposes, which meant that no effort was ever made to bring European and Indigenous worldviews closer to each other. This was due to the European belief in a universal consciousness and a universal god that clashed with Indigenous beliefs:

Most Indigenous people view the world as independent of their beliefs about it. It is an external reality that is in a continuous state of transformation. The entire universe is seen as creative local space, as sacred realms of change. Together the realms create a flowing, transforming existence. Each realm is related to the movement and is described only in order to understand the process of change. The energy of the realms comes with transformations. (ibid., p. 40)

The result of this wilful ignorance on the part of Europeans was the superimposition of their concepts over Indigenous ones that led to the extinction of many Indigenous peoples along with their languages and beliefs. As is well-known, the majority of those who survived were assimilated into Christianity and European languages over the course of a "five-hundred-year nightmare of destruction" (ibid., p. 42). The system of residential schools, finally addressed by the TRC, resulted from the same tradition and no apology will ever be truthful if this history is not learned and truly understood by settlers, as our chosen epigraph eloquently demonstrates (Robinson and Martin, 2016 p. 1). Part of this understanding will have to take into account the Eurocentric illusion of benign translatability.

One of the main goals of the field of translation studies has been to have translation recognized as an important object of critical inquiry and to bring awareness to other fields and to the general public that the practice and theory of translation have to be 
taught-dictionaries are not sufficient-because the transfer into a different language and culture is fraught with difficulties. Translators and receivers need to understand that the source text undergoes transformation and that this process is never benign. Listing several examples, among which the near impossibility of "translating common law into French and civil law into English [...] [or] the fact that some ideas do not exist in all languages of a linguistic family" (2000, p. 41), Battiste and Henderson pointedly ask:

how can governments and scholars assume that differently constructed worldviews, such as those available within Indigenous languages, are not only translatable into English and French, but translatable without substantial damage or distortion? (ibid.).

Inspired by Battiste and Henderson, Ashininaabe scholar Maya Odehemik Chacaby uses stories to build an article on the notion of benign translatability. The main story is Ojibway and portrays the First Teacher, or a benign entity, who defecates on the baby birds who translated his name for him: "This benign entity then continues about his day without any concern for the consequences. But there are consequences. And they are not benign" (Chacaby, 2015 , p. 1). In order to begin imagining translation as a potential tool of decolonization, and "to arrive at a place where translation becomes real naming and saves us from our self-destruction" (ibid., p. 3), it is important to learn the concepts of language in Indigenous cultures since language is paramount in any decolonizing effort in education. A necessary first step for settlers and allies is to consider why and how Indigenous language families are different from nonIndigenous ones.

\section{Language, Land and Translation}

The language loss experienced by colonized Indigenous peoples can be viewed as deterritorialization. Chacaby describes the Eurocentric classroom environment for those who wish to learn the language of their ancestors as a form of diaspora. Students long for home, "for real connections to Elders, knowledge holders and Anishinaabeg pedagogies" (ibid., p. 7). Unfortunately, they can only access the language and those relationships "through mediatized, commodified, Eurocentric packaging (books, DVDs, posters)" (ibid.). She goes on to say that the language resources and translations used in this $\mathrm{Eu}-$ rocentric methodology are separated from the "high-context Anishinaabe worldview," and therefore useless (ibid.). This means that 
Indigenous learners can only reconnect with their language if they reconnect with the worldview that has shaped it. It also suggests that a thorough revision of both language and translation teaching methods is absolutely necessary to implement decolonization of education. As noted above, the world is an external reality always in transformation, and Battiste and Henderson explain that, for example, in "the Algonquian worldview, perceptions, under certain conditions, do provide an accurate impression of reality. These impressions are not directed at external forms of life, however, but to understanding the invisible forces beneath the external forms" (2000, p. 40). Furthermore, the Mik'maw language, also made of forces related to the perceived world, "builds on verb phrases that contain the motion of the flux, with hundreds of prefixes and suffixes to choose from to express a panorama of energy" (ibid.). Several of our participants commented on Nehiyaw being a "context" language, meaning that structurally it is also connected to invisible forces, such as feelings and spirit. Reuben Quinn, the coordinator of the university's Nehiyaw language program, always starts his teaching, as he did for our interview, by outlining the Nehiyaw Cahkipeyihkanah, or Star Chart, that represents all the sounds of the language according to the cardinal points ${ }^{6}$. Chacaby argues that Anishinaabemowin is "one big language" (2000, p. 8), that it does not matter if two people talking to each other come from two different places since "local preferences are respected, not usurped or replaced. In the urban diaspora, it is possible to include everyone's syntactic inclinations, orthographies and word preferences in creative ways, if only we used Algonquian pedagogies" (ibid., p. 8). This is not an argument that speakers of other languages would necessarily accept but it is powerful for avoiding Eurocentric language revitalization. It also introduces the notion of space that is central to most Indigenous languages and which we explain next.

Chacaby further argues that what she calls "refraction"- "the filtering of Indigenous ways of knowing through the European lens" (ibid., p. 7) - "produces more than dialectical divides. It also creates problematized spaces where our mother-tongue speakers are delegitimized and filtered out in the translation process" (ibid., p. 8). Quoting both Douglas Robinson (1997, p. 158) and Battiste and Henderson (2000, p. 81), she points out that the traditionally

6. For more information on the history of the Nehiyaw language, watch both his YouTube presentations (Quinn, 2016a, 2016b). 
"assumed 'sense-for-sense/word-for-word' translation is a suppression of difference, where colonists are sheltered from heterogeneity and [...] [peripheries] [...] find it necessary to "write for translation" (Chacaby, 2015, p. 8; italics in original). Early in his article about rights and reconciliation, Mark Fettes quotes a paragraph from the Assembly of First Nations' report entitled "Towards Linguistic Justice for First Nations" (1990), which is worth reproducing here in its entirety:

The most important relationship embodied by First Nation, Inuit and Métis languages is with the land. "The land" is more than the physical landscape; it involves the creatures and plants, as well as the people's historical and spiritual relationship to their territories. First Nation, Inuit and Métis languages show that the people are not separate from the land. They have a responsibility to protect it and to preserve the sacred and traditional knowledge associated with it. (Assembly of First Nations, quoted in Fettes, 2016, p. 3)

Fettes also quotes numbers $13-15$ from the TRC report that deal with language to show that "land" is never mentioned. Number 13 brings attention to Indigenous languages as a human-rights issue; number 14 to a semi-autonomous domain of legislation and redistributive action" (ibid., p. 4); number 15 to an oversight mechanism ${ }^{7}$. While he admits that these "are true-and-tried methods of putting a social issue on government agendas" (ibid., p. 4), he does "wonder whether something has been lost in this process of translation" (ibid.).

7. Our own analysis of the language sections of the TRC report reveals that "Language and Culture" recommendations are listed under "Legacy" and consist of a mere five recommendations, numbered 13-17 (Truth and Reconciliation Commission of Canada, 2012, p. 2), while the term "language" appears only six more times in the entire document. Call to Action number 14 is divided into the five principles of a new Aboriginal Languages Act to be enacted. In summary, they cover: the urgency to preserve Indigenous languages; the protection offered to them by the treaties; the Federal government's responsibility to fund their revitalization and preservation; the fact that revitalization, preservation and strengthening are best managed by Indigenous communities; that funding must reflect the diversity of Indigenous languages. Call to Action number 15 asks for the appointment of an "Aboriginal Languages Commissioner" (ibid.) and Call to Action number 16 states: "We call upon post-secondary institutions to create university and college degree and diploma programs in Aboriginal languages" (ibid.). With regards to number 15, Prime Minister Justin Trudeau announced on December 6, 2016 that an Aboriginal Languages Commissioner would be appointed but, while Raymond Théberge was named new Official Languages Commissioner in November 2017, no such appointment has been made to date. 
Like Chacaby, he criticizes the implied Eurocentric management of Indigenous languages and offers possible alternatives; he further points to the English way of using nouns to designate languages "as if they were discrete things" (ibid.), which also turns them into more "homogenous and predictable" things than they really are (ibid.). Fettes goes on to explain that language is related to the environment and that, in Indigenous worldviews, this is paramount because language is viewed as deeply relational and individuals are "complexly situated within those networks of relations" (ibid., p. 6). This intricate connection between language and land can, therefore, be the source of language revitalization and environment protection, if undertaken with a decolonizing approach. In the same way that a European scientist will remove a plant from the ground in order to study it, a language taught in a classroom will only retain "the faintest echoes of a living culture, and almost no sense of the more-than-human world and places that sustain this culture" (ibid., p. 7). According to Choctaw scholar Rain P. Cranford Goméz, this connection also represents "the incessantness of memory and land (memory and Indigenous assertions or presentness), not as historic or haunting but as an ever-present reality tied to place, race, and regionality" (2014, p. 90). She goes on to explain:

[i]f we think of events not as historical, but as acts on land (geographically connected), then time is not a linear factor linking happenings; those events become land based, linked to the people who occupy certain spaces. (ibid., p. 91)

Given the North American fact that universities are mostly located on treaty land, Métis or unceded territories, events tied to the process of reconciliation on campus acquire a special significance for Indigenous people reclaiming "[their] own story, the record keeping of [their] land, and [their role] as active participants in [their] intersecting pasts, presents, and futures" (ibid.). Land acknowledgments that many units and individuals at the University of Alberta have adopted are a step in the right direction, although they do run the risk of tokenism ${ }^{8}$. Papaschase Chief Calvin Bruneau, who has collaborated in many events on campus, shared with us that these acknowledgments would be more efficient if they included the term "host" in their formulation, thus underscoring the notion that

8. For more details about the different versions of the Territorial acknowledgements proposed officially by the University of Alberta, see University of Alberta (n.d.). 
the university is a guest on traditional territory. Another step in the right direction is the Privilege Walk Lesson Plan (an experiential activity to highlight how people benefit from or are marginalized by systems in our society), developed by a professor in the Department of English and Film Studies. At the beginning of the term, students are led on a walking tour of campus as a way to acknowledge Treaty 6 and the university's colonial past. Another professor, from the School of Public Health, resorts to the Circle Protocol/Process in her teaching to have students interact in an inner and collective space that acknowledges the university's location on Treaty 6 territory. Some efforts are also being made to create inclusive spaces on campus where students and staff can gather with the aim to learn more about Indigenous cultures and history. For example, an Aboriginal Gathering Space was created in the Faculty of Arts in late 2016. That new space is meant as "a restful space for conversation and community building" (McKinnon, 2016, n.p.). An Elder shares traditional knowledges and consults once a month there. On a larger scale, and still in the works, the centre for Aboriginal students, called The Maskwa House of Learning, was announced by president David Turpin in fall 2015 (Boyd, 2016, n.p.).

In terms of symbols, traditional art pieces have recently been displayed on campus. The Sweetgrass Bear, of which there are other smaller versions in Enterprise Square and Augustana Campus, was inaugurated at the North Campus's Main Quad in August 2016 (University of Alberta, 2018b, n.p.). The inscription "We're all related" serves as a sign of reconciliation for the campus community. Other pieces were also on loan for a year by the same artist, Stewart Steinhauer, and exhibited from fall 2017 in the same space?. The Main Quad is a strategic central location for those pieces on North campus, insofar as it is situated at the foot of Pembina Hall, which houses the Faculty of Native Studies.

These examples are part of many strategies that are encouraged to heighten Indigenous visibility on campus and raise consciousness. To effect real change in western thinking and practices, however, much more is required, and there is a need to include the problematics of translation in any decolonizing process or the illusion of benign translatability will endure. Our investigation of the presence of translation on campus, including in digital spaces, has revealed several issues, a few of which are discussed in what follows.

9. For more details about the pieces exhibited, see University of Alberta (2018c). 
Translation into English could be seen as a pharmakon, which is both a remedy and a poison. On the one hand, it is celebrated by several interviewees as a very good way to share knowledge and engage with the audience and, we argue, it can be seen as a performative act. On the other hand, it runs the risk of maintaining the illusion that Indigenous languages can be translated without loss or damaging transformation. One of the benefits is to foster a sense of community, either by including the potential receiver in the strategy of communication, or by acknowledging cultures that have no previous history of being acknowledged. A very good illustration of performativity would be to consider the translation of some texts or public meetings into an Indigenous language to keep records of it for future generations. Keeping records in an Indigenous language would be a purposeful statement of language continuity and survival, as mentioned by one participant (Anon., 11 October 2017).

However, the potential problems are numerous. The choice of translation is always a thorny question and it has its opponents in a post-colonial era. Our corpus revealed a certain opacity surrounding translation in electronic communication and documents. It seems that insufficient time is given to individuals tasked with preparing messages about events and it is unclear how the texts have been translated, as well as which Indigenous languages have been used. While Nehiyaw is the dominant language in Alberta, there are notable differences in dialects, such as Mountain Nehiyaw and Plain Nehiyaw, for example. If the twofold goal we set for ourselves is to have "new knowledge come in by opening up our minds and our hearts" (Buffalo, 2016, n.p.), and to "make sure that there is no breakdown in communication" (ibid.), to echo Elder Marilyn Buffalo, a coherent linguistic strategy needs to be implemented in the long run. It must be remembered that acquiring new knowledge takes time but also that practice, in as small a thing as sending out a notice about an event, needs to match the rhetoric of "decolonizing education." The university community is in the very first phase of being educated on Indigenous cultures and worldviews, and this "enlightenment" would benefit from a gradual approach. Opacity could be avoided if some strategies were put into place, such as the creation of an online terminological reference guide, or the use of other resources, like explicitation ${ }^{10}$, notes or, in those cases where it is

10. Explicitation is "a translation procedure where the translator introduces precise semantic details into the target text for clarification”(Delisle et al., 1999, p. 139). 
not used, interlingual translation. Interestingly enough, interlingual translation and explicitation are often used in oral communication and seen by participants as natural to guarantee the clarity of the message, but they are more rarely used in written communication where Indigenous terms appear in English. The opacity is mainly due to a lack of education about Indigenous languages on the receivers' part. At times, several Indigenous languages are used, either in the same document or in the various documents that circulate within the University setting, as in this greeting banner with "hello" in many languages:

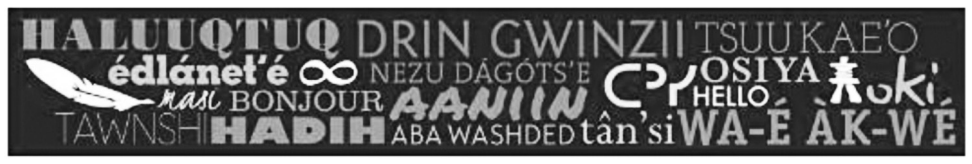

Image 1. Banner with "hello" in many languages ${ }^{11}$

Identifying which languages are featured in those texts would of course dispel part of the opacity and would also enhance the visibility of those languages, while paying tribute to them at the same time. Similarly, syllabics have a very special value in Indigenous languages. According to Quinn, the system of forty-four Nehiyaw syllabics represents their "symbiotic relationship with the four elements" (8 November 2017), which is why they are named "spirit markers." Quinn also points out that, contrary to the linear Roman alphabet, spirit markers are organized in a lateral way (2016a, n.p. ${ }^{12}$. Thus, should one decide to use this alphabet in a territorial acknowledgement, as was suggested by some departments, guidance as to their symbolic value would prove valuable to the user. Keavy Martin (6 October 2017), for instance, described her decision to no longer use the syllabics in her staff signature after realizing that they were embedded in a nêhiyaw legal system that she did not fully grasp. Finally, a lack of clarity may also result from the use of

11. The home page of the Arts Indigenous Network featured this representation back in 2016 and it is now featured at the bottom of the main web page of the Indigenous initiatives undertaken by the office of the Provost and the VicePresident. The banner can be found at the following address: https://www. ualberta.ca/provost/our-initiatives/indigenous-initiatives.

12. This concept is related to the differences between western and Nehiyaw pedagogies. Quinn points to a paradigm in which "the method is heuristic, the learning organic and the system requires lateral thinking” (2016a). 
inter-sentential and intra-sentential code-switching (O'Shannessy, 2011 , p. 82). In the case of inter-sentential code-switching, the semantic tie between the Indigenous language and the English language may not be clear, as in the following announcement: "Métis Kitchen Party: pê-chikis tamakêk." 13 Is "pê-chikis tamakêk" new information or is it, rather, the translation of "Métis Kitchen Party"? A guess is not sufficient for the purpose of learning. Regarding intra-sentential code-switching, one may have difficulty in making sense of the use of one word in different linguistic contexts, as is the case, for instance, for "Amiskwacîwâskahikan." The word means "Beaver Hills," and is used with two different prepositions, "in" and "on," as exemplified by the two occurrences that follow: "We honour our location in $\varangle \Gamma^{n} \mathrm{~b} \cdot \dot{\Gamma}\left\langle\cdot \mathrm{n}^{\prime \prime} \Delta \mathrm{b}^{\supset}\right.$ (Amiskwacîwâskahikan) on Treaty 6 territory." ${ }^{4 /}$ "Panel on what it means to be a university on Amiskwacîwâskahikan/Treaty 6/Métis river lands."

In the next section we will look in more detail at several examples of translation in order to examine how it is practiced by speakers at events organized to promote the indigenization of academia. We will then suggest how this practice can be extended further, taught in our courses, and shared with colleagues.

\section{Activist Translation of Indigeneity}

Tawow, Welcome in Nehiyaw. Wilihowtek, Welcome in Takelma. We are in Amiskwacîwâskahikan, Beaver Hill House, the traditional Nehiyaw name for Edmonton. (Ward, 27 September 2017)

On 27 September, 2017, at the Centre for Teaching and Learning's session on "Indigenous People and Place: Indigenizing Education," Jennifer Ward started by welcoming everyone in Nehiyaw and in her Native language (Takelma, which is an Athabascan language, whereas Nehiyaw is an Algonquin language). She also used the Nehiyaw name of Edmonton in her land acknowledgment. During our interview, Ward, an education developer with the Centre for Teaching and Learning and one of our participants, explained that it

13. Please see the Facebook page at https://www.facebook.com/events/u-of-avan-vliet-physical-education-rec-ctr/m\%C3\%A9tis-kitchen-party-p\%C3\%AAcihkis-tamak\%C3\%AAk/174324463140767/ for more information on the event. 14. Back in 2016, the acknowledgement of the location of the University of Alberta on Treaty 6 territory was written in the aboriginal alphabet (Cree syllabics) and transliterated into the latin alphabet in Cree at the bottom of the home page of the Arts Indigenous Network. 
is key to her to show that she is honouring the land and space we are in. She also emphasized the importance of the idea of a connection to a place in Indigenous worldviews and identities.

tân'si kahkiyaw kitatamiskatinâwâw wâpikihewiskwew ninehiyawiwihowin ekwa anonymous nimôniyâwiwihowin. minahikosihk ohci niya maka ota niwikin amiskwacîwâskahikanihk. (Anon., 22 September 2017)

Hello, greetings to all. My Nehiyaw name is White Eagle woman and anonymous is my English name. I am from Little Pine First Nation but I reside here in Edmonton. (ibid.)

This is the opening greeting of a panel held in 2017 at the University of Alberta. The participant shared with us that they had decided to use Nehiyaw, their first language, to introduce their identity as a Plains person "because it is their first language, it is who they are, and it is very important to share this with others" (Anon., 11 October 2017). To use their first language is a way for the participant "to speak from the heart" $(\mathrm{ibid}$.). It is a question of Truth: "Our language is a living spirit and is interconnected to our culture in a very rich and meaningful way" (ibid.). Further, the participant explained that their "language and culture is absolutely important to them as this is what was given to us (Plains Nehiyaw) by the Creator" (ibid.). The participant made the choice during the talk to explain that English is their "borrowed" language and chose to translate the opening greeting into English so that everybody could understand what it meant.

Another participant (Anon., 22 September 2017) explained that it is very difficult to capture the same message in English and in Nehiyaw. There is, for example, a difference in meaning between the term "Reconciliation" and its translation "Wahkotowin [sic]"15 in Nehiyaw (as it appears in the online advertisement of the conference bearing that name); the Nehiyaw word is more a synonym of "relations" than a translation as it is very difficult to find an equivalent for the English term in Nehiyaw. Similarly, the syllabic word in Nehiyaw used for "Hello," "C $\sigma$ r," means more than the English word, since it also implies "how are you?" (ibid.).

In a post-colonial context, translation can be seen as a symbolic space of reconciliation between languages that were not allowed

15. Description used for the program of "Panels, Talks and Performances" that took place at the University of Alberta on October 21, 2016. Also note that in materials produced by students in a course taught by Quinn, the Cree term for "reconciliation" is spelled wîcehtowin. 
to coexist synchronically side by side or in one voice. The opening words by Indigenous panelists introducing themselves in their mother language and translating into English are the same types of discourse identified by Jocelyn C. Ahlers (2006, p. 63) in her analysis of the public use of Native American languages, in her case by nonfluent speakers only. The fact that the talks gave pride of place to the Indigenous language in that framed portion of the talk and that English came second, either because the introduction or the greetings were made in the Indigenous language only, or because the two languages were used in the process of translation, was both a powerful act of decolonization and an instance of reconciliation through languages. Even though some speakers were fluent in their heritage language, we think that Ahlers' analysis of the use of Native languages in such a context as being "both a performance and performative" (ibid., p. 64) is valid. In this sense, these framed discourses can be seen as "intercultural performances of Aboriginal identity," to borrow the term from Stephen Peters (2014, p. 430). As such, they represent "a very particular way to perform identity, to serve as a form of cultural capital within the broader Native community, and to frame a speech event as coming from a Native perspective" (Ahlers, 2006, p. 72).

Finally, while it is true that our Indigenous interviewees are mostly in favour of translating Indigenous occurrences into English, they are also aware that it is the settlers' language and that, as such, it is "associated with the group whose hegemony has, in many cases, led to the endangerment of the community's heritage language" (ibid., p. 58). The refusal to translate is also very meaningful in this context, as it becomes a political gesture:

The colonial attitude, including its academic branch, is characterized by a drive to see, to traverse, to know, to translate (to make equivalent), to own, and to exploit. [...] Primary sites of resistance, then, are not the occasional open battles between the minoritized, oppressed, or colonized and the dominant culture, but the perpetual, active refusal of complete engagement: to speak with one's own in one's own way; to refuse translation and full explanations; to create trade goods that imitate core culture without violating it; to not be a Native informant. (Garneau, 2012, p. 32; our italics)

One of the pioneers of resistance is Kim Anderson, who proposed in the introduction to her book on 40 Canadian Indigenous women "that women engage in a process of self-definition that includes 
four steps: resist, reclaim, construct and $a c t^{\prime \prime}(2000$, p. 16; italics in the original). Taking up this call, Chacaby links it to translation:

Resist Eurocentric translations; they are a myth that teaches us that we are broken and repairable only through the thinking of the colonizers. Resist grammatical functionality as the rehabilitation of our language (it is a lie). Mistranslate. Resist resigning ourselves to the limitations imposed through translation. Go and sit with those Elders who were missed and mistranslate to include all their jokes and stories. Reclaim those facts unfit to fit-they are the ones that really matter (and are usually hilarious). Construct through creative retranslation. This reconstruction, this mistranslation leads to a certain kind of action: a conscious willingness to give up the disabling language of the colonizer. (2015, p. 9; italics in original)

We believe that those four steps can be considered the corner stones of activist translation in the context of a university seeking to decolonize and indigenize. Resistance to Eurocentric methods comes first; reclaiming language and culture is part of reclaiming territory and identity; constructing depends on creativity to build new structures and practices; actions are the only way to accomplish the goal of changing mindsets. Carrie Dyck calls for the creation of an "ethical space" (2011, pp. 17-18) for different worldviews to come into contact: "Instead of just acting and reacting, participants within an ethical space purposefully examine their underlying motives and the effects of their interactions" (ibid.). In other words, like other initiatives happening on campus, translation and its teaching need to be collaborative with Elders or Indigenous specialists in the field. Furthermore, Brian Swann argues that there is a need for cultural translation, which is "the result of the history of the Americas" (2011, p.2). As we discussed in the section on western epistemology and translation, Europeans interpreted Indigenous cultures according to their own terms, and ignored their artifacts when they did not destroy them. This cultural genocide is part of the collective trauma, and activist translation, as it is defined here, can help in reclaiming and reconstructing cultures while resisting the illusion of benign translatability. We adopt the term "cultural translation," as defined by Swann and as encompassing the practice of translation itself. As underlined by Moira MacDonald in her article "Indigenizing the Academy," "spaces and symbols," "academic programs and resources," (2016, n.p.) and "events" are part of the general endeavour, and activist translation needs to be an important part of it. In fact, 
ceremonies and rituals can be seen as concrete cultural translations of Indigenous identity, as a way of "re-presenting" and "performing" what it means to be Indigenous on Treaty 6 and Métis territory. Whether they are organized as events of their own or as part of other more formal events, they often showcase Indigenous languages, potentially providing the opportunity to create ethical spaces and practice activist translation. As such, they are attempts at "reinscribing" Indigeneity into cultural practices, or "acts on lands," as Cranford Goméz has argued (2014, p. 91).

\section{Conclusion}

The learning process that we have engaged in during our investigation is ongoing. As professors we have the responsibility to teach what we have learned, and we do our part to integrate Indigenous history and culture into our courses. Our translation program, however, consists of European languages, so the task is challenging. One of us is planning to learn Cree when time allows, and the reasons behind our proposal for activist translation together with its components can be added to the theories that we teach. This actually enriches our teaching because it helps students learn with a critical outlook on the matter. The history of Cree syllabics, and how it is currently taught in translation studies programs across the country, can be taken as an illustration of the vast differences that often exist between settler and Indigenous systems of education. It has long been accepted within the field that James Evans "invented" Nehiyaw syllabics in the 1840s at Norway House in northern Manitoba, a region managed at the time by the Hudson's Bay Company. Using as a model the Ojibway syllabary that he had developed with the collaboration of Ojibwa native speakers in Ontario, he devised the Nehiyaw alphabet with his collaborators, Henry B. Steinhauer-whose Ojibwa name was Sowengisik-, Chipeyan interpreter and guide Thomas Hassall, John Sinclair, and Reverend William Mason and his wife Sophia Thomas, a Nehiyaw woman who translated the Bible into that language (Woodsworth and Delisle, 2012, p. 18, n. 15). However, another story exists: that of Badger Call (Mestanuskwe-u), as told by "Nehiyaw Warrior and Holy Man" Fine Day (Hungry Wolf, 1973, p. 1) and recorded in My Nehiyaw People by anthropologist David Mandelbaum in 1934 (Fine Day, 1973, pp. 58-59). It is difficult for settlers to accept this version because it involves Mestanuskwe-u dying, being given the syllabics, and coming back to 
life, ready to use and teach them. The story says that it was he, also a famous doctor, who gave them to the missionaries. The co-existence of these two stories is an issue for translation scholars and educators, and, by extension, for settler educators in general. Indeed, how are we to modify teaching methods in order to acknowledge the colonial nature of Canada's history and re-integrate Indigenous worldviews into Canadian culture? Lisa Cook advocates education from two points of view because, she argues, to “Indigenize education' is to put our native education into a box and teach from a European interpretation" (2017, p. 23). Our participant Ward shared with us that she sees it differently: "I'm always very open about the fact that we have to look at both sides and our goal is to bring Indigenous perspective whenever and wherever we can, and Indigenous persons should be at the forefront of that" $(2017$, n.p.). We take this suggestion to heart since true collaboration can only happen if both sides respect each other's beliefs and learn from them, and since the next phase of our project will involve coming up with curriculum changes both in translation and cultural content courses.

The story of Badger Call also reminds us of the importance of stories in Indigenous cultures, as both Anderson and Chacaby have shown in their own work. Daniel Heath Justice talks about the good stories - those that "give shape, substance, and purpose to our existence and help us understand how to uphold our responsibilities to one another and the rest of creation" $(2018$, p. 2). He notes, however, that not all stories are good and that many

are toxic, and to my mind, the most corrosive of all is the story of Indigenous deficiency. We've all heard this story, in one form or another. According to this story, Indigenous people are in a state of constant lack: in morals, laws, culture, restraint, language, ambition, hygiene, desire, love. (ibid:; italics in original)

As we have tried to show, colonialism and attempted cultural genocide have caused trauma that has lasted for generations and continues to affect many individuals and families. As we look to the future and consider further possibilities to co-exist equitably with First Nations, Métis Nations and Inuit Nations, we acknowledge that the process will need to go on forever and more may need to be done at the grassroots level to ensure perpetual activism as governments, policies, and funding change. As we have seen, both theorizing, in the form of formal or informal meetings and discussions, and concrete changes in curricula and policies will have to continue in 
order to come closer to possible agreements on what constitutes "reconciliation," "decolonizing education," and "Indigenizing the university." In September 2016, Métis anthropology professor Kisha Supernant wrote in a blog after two days of the $2^{\text {nd }}$ Building Reconciliation Forum that she was "left thinking about what the future holds for universities in the wake of the TRC Calls to Action" (2016, n.p.), and that "perhaps we need to think about building conciliation, rather than reconciliation" (ibid.). We borrow from her to conclude on a note of optimism: "As academics, we have much work to do. But if we are courageous, open our hearts, and commit to the hard work of what Willie Littlechild calls 'reconcili'action', we can change the academy and the world" (ibid.).

\section{References}

Ahlers, Jocelyn C. (2006). "Framing Discourse: Creating Community through Native Language Use." Journal of Linguistic Anthropology, 16, 1,pp. 58-75.

Andersen, Chris (22 September 2017). Edmonton.

Anderson, Kim (2000). A Recognition of Being: Reconstructing Native Womanhood. Toronto, Second Story.

Anon. (22 September 2017). Edmonton.

Anon. (11 October 2017). Edmonton.

Battiste, Marie and James (Sa'ke'j) Youngblood Henderson (2000). Protecting Indigenous Knowledge and Heritage: A Global Challenge. Saskatoon, Purich Publishing.

Bear, Tracy and Chris Andersen (2017). "Three Years Later, is Canada Keeping its Truth and Reconciliation Commission Promises?" The Globe and Mail, April 21. Available at <https://beta.theglobeandmail. $\mathrm{com} /$ opinion/three-years-later-is-canada-keeping-its-truth-andreconciliation-commission-promises/article34790925/?ref=http:// www.theglobeandmail.com\&> [consulted 5 August 2017].

Boyd, Alex (2016). "Fighting Prejudice on Campus." StarMetro, 29 September. Available at <https://www.pressreader.com/canada/metro-canadaedmonton/20160929/281522225578149> [consulted 12 January 2017].

Bruneau, Chief Calvin (9 August 2017). Edmonton.

Buffalo, Marilyn (2016). "Introduction." Truth and Reconciliation, Good Relations, and Indigenizing the Academy. Panel held at the University of Alberta, October 21. Available at <https://livestream.com/ualberta/ events/6515900/videos/139324756> [consulted 12 January 2017].

Chacaby, Maya Odehamik (2015). "Crippled Two-Tongue and the Myth of Benign Translatability." Tusaaji: A Translation Review, 4, 4, pp. 1-11. Cook, Lisa (2017). "We Need to Work Together. That's How it was Meant to Be." New Trail, May 24. Available at <https://www.ualberta. 
ca/newtrail/spring-2017/features-dept/need-to-work-together > [consulted December 2017].

Cranford Goméz, Rain P. (2014). “Hachotakni Zydeco's Round'a Loop Current: Indigenous, African, and Caribbean Mestizaje in Louisiana Literatures." The Southern Literary Journal, 46, 2, pp. 88-107.

Delisle, Jean, Hannelore Lee-Jahnke and Monique C. Cormier, eds. (1999). Terminologie de la traduction/Translation Terminology/Terminologia de la Traducción/Terminologie der Übersetzung. Amsterdam/Philadelphia, John Benjamins.

Dempsey, James (8 August 2017). Edmonton.

Dyck, Carrie (2011). "Should Translation Work Take Place? Ethical Questions Concerning the Translation of First Nations Languages." In B. Swann, ed. Born in the Blood. On Native American Translation, Lincoln/London, University of Nebraska Press, pp. 17-42.

Eidinger, Andrea (2017). "(Re)learning Indigenous History in Canada." Unwritten Histories. The Unwritten Rules of History. June 27. Available at $<$ http://www.unwrittenhistories.com/relearning-indigenous-historyin-canada/ $>$ [consulted January 2018].

Fettes, Mark (2016). "Land and the Living Roots of Language: From Rights to Reconciliation." Tusaaji: A Translation Review, 5, 5, pp. 1-16. Fine Day (1973). “The Story of Badger Call.” In My Nebiyaw People. Invermere, Good Medicine Books, pp. 58-59.

Garneau, David (2012). "Imaginary Spaces of Conciliation and Reconciliation." In J. Dewar and A. Goto, eds. "Reconcile This!" West Coast Line, 74, pp. 28-38.

Government of Canada, Canadian Heritage (2017). Important Step Taken Toward Co-Development of Indigenous Languages Legislation in Meeting Between Government of Canada, Métis, Inuit and First Nations Leaders. [News Release] June 15. Available at <https://www.canada.ca/en/ canadian-heritage/news/2017/06/important_step_takentowardco-dev elopmentofindigenouslanguagesleg.html $>$ [consulted 20 January 2018].

Hungry Wolf, Adolf. (1973). "Introduction." In My Cree People. Invermere, Good Medicine Books, pp. 1-3.

Justice, Daniel Heath (2018). Why Indigenous Literatures Matter. Waterloo, Wilfrid Laurier University Press.

MacDonald, Moira (2016). "Indigenizing the Academy." University Affairs/Affaires universitaires, April 6. Available at <http://www. universityaffairs.ca/features/feature-article/indigenizing-theacademy/> [consulted 1 September 2016].

Martin, Keavy (6 October 2017). Edmonton.

McKinnon, Donna (2016). "A Place of Belonging." Faculty News, October 27. University of Alberta, Faculty of Arts. Available at <https://www. ualberta.ca/arts/faculty-news/2016/october/a-place-of-belonging> [consulted 20 March 2017]. 
Mooridian, John K. et al. (2006). "Across Generations: Culture, History, and Policy in Social Ecology of American Indian Grandparents Parenting their Grandchildren." Journal of Family Social Work, 10, 4, pp. 81-101.

O'Shannessy, Carmel (2011). "Language Contact and Change in Endangered Languages.” In P. K. Austin and J. Sallabank, eds. The Cambridge Handbook of Endangered Languages. Cambridge, Cambridge University Press, pp. 78-99.

Papaschase First Nation (n.d.). Papaschase... All my Relations. Available at $<$ https://www.papaschase.ca/> [consulted 21 July 2019].

Peters, Stephen K.H. (2014). "The Rhetorics of Urban Aboriginal PlaceMaking: Studying Aboriginal and Non-Aboriginal Relationship Building in the Intercultural Speaking Event." Proceedings of the Annual Meeting, Berkeley Linguistics Society, Available at <https:// journals.linguisticsociety.org/proceedings/index.php/BLS/article/ view/3151/2870> [consulted 2 December 2018].

Pratt, Mary Louise (1991). “Arts of the Contact Zone." Profession, pp. 3340.

Quinn, Reuben (2016a). "History of the Cree Language Part 1." Amiskwaciy History Series. Available at <https:/www.youtube.com/ watch?v=CpvuED_hJTM $>$ [consulted 15 March 2017].

Quinn, Reuben (2016b). "History of the Cree Language Part 2." Amiskwaciy History Series. Available at <https://www.youtube.com/ watch?v=PuHofizOjiY> [consulted 15 March 2017].

Quinn, Reuben (8 November 2017). Edmonton.

Robinson, Dylan and Keavy Martin, eds. (2016). Arts of Engagement: Taking Aesthetic Action In and Beyond Canada's Truth and Reconciliation Commission. Waterloo, Wilfrid Laurier University Press.

Supernant, Kisha (2016). "On Reconciliation in the Academy." metisarcheologist [blog], 30 September. Available at <https:// metisarchaeologist.wordpress.com/> [consulted 16 November 2017].

Swann, Brian, ed. (2011). Born in the Blood: On Native American Translation. Lincoln/London, University of Nebraska Press.

Truth and Reconciliation Commission of Canada (2012). Truth and Reconciliation Commission of Canada: Calls to Action. Available at $<\mathrm{http}: / / \mathrm{trc}$. ca/assets/pdf/Calls_to_Action_English2.pdf> [consulted 20 August 2017].

Truth and Reconciliation Commission of Canada (2015). Honouring the Truth, Reconciling for the Future: Summary of the Final Report of the Truth and Reconciliation Commission of Canada. Available at <http:// www.trc.ca/websites/trcinstitution/File/2015/Honouring_the Truth_Reconciling_for_the_Future_July_23_2015.pdf> [consulted 1 September 2016].

United Nations (2008). United Nations Declaration on the Rights of In- 
digenous Peoples. Available at <http://www.un.org/esa/socdev/unpfii/ documents/DRIPS_en.pdf> [consulted 20 August 2017].

University of Alberta (n.d.). "Acknowledgement of Traditional Territory." Marketing \& Communications Toolkit. Available at <https://www. ualberta.ca/toolkit/communications/acknowledgment-of-traditionalterritory> [consulted 20 September 2017].

University of Alberta (2018a). Aboriginal/Indigenous Index of Web Links. Available at $<$ https://www.ualberta.ca/aboriginal-indigenous > [consulted January 2018].

University of Alberta (2018b). "Unveiling the Sweetgrass Bear." In the Community. Available at <https://www.ualberta.ca/president/in-thecommunity $>$ [consulted 15 January 2018].

University of Alberta (2018c). "Sculptures Reflect on Conversations with the Rock Grandfather." News. University of Alberta Museums. Available at <https:/www.ualberta.ca/museums/news/2017/october/ sculptureconversationswithrockgrandfather $>$ [consulted 5 November 2017].

University of Toronto/Université Laval (2003-2019). Dictionary of Canadian Biography. Available at <http://www.biographi.ca/en/> [consulted 31 January 2018].

Ward, Jennifer (27 September 2017). "Indigenous People and Place: Indigenizing Education." Edmonton.

Ward, Jennifer (16 October 2017). Edmonton.

Woodsworth, Judith and Jean Delisle, eds. (2012). Translators through History. Edition revised and expanded by J. Woodsworth, Amsterdam/ Philadelphia, John Benjamins.

Anne Malena

Department of Modern Languages and Cultural Studies

University of Alberta Edmonton, Alberta, Canada amalena@ualberta.ca

Julie Tarif Department of Modern Languages and Cultural Studies University of Alberta Edmonton, Alberta, Canada jtarif@ualberta.ca 